\title{
A CASE OF LATE CONGENITAL SYPHILITIC LABYRINTHITIS
}

\section{-WITH REFERENCE TO HENNEBERT'S SIGN, FLUCTUATING HEARING, HERXHEIMER REACTION AND THERAPEUTIC RESPONSE OF IMPAIRED HEARING-}

TAMIO KAMEI, M.D., HIDEO ISHII, M.D. Department of Otolaryngology, School of Medicine, Gunma University, Maebashi

(Director: H. Ishii, M.D.)

TAKUO OKAWA, M.D.

Ear, Nose and Throat Clinic, Red Cross Hospital, Maebashi

BUNSUKE SATAKE, M.D.

Division of Head and Neck Surgery, Gunma Cancer Center Hospital, Ohta

MASARU YODA, M.D.

Ear, Nose and Throat Clinic, National Hospital, Takasaki

A case of late congenital syphilitic labyrinthitis (male, first examined at 35 years of age) which has been observed over a long period (for a total of ten years) is described along with a discussion on the clinical findings.

1. A positive fistula test with an intact tympanic membrane, or Hennebert's sign, was evident in both ears over a period of about one year. The form of induced mystagmus, which lasted for 1 to 2 seconds with 1 to 3 beats, was chiefly vertical with strong rotatory elements. From these findings the underlying pathogenetic mechanism of the sign in the present case was inferred to be due to pressure transmission via the oval window. The direction of the nystagmus was reversed on positive and negative pressure.

2. Marked fluctuations in auditory thresholds were noted in both ears over a period of years. The patient further showed a tendency for the auditory disturbance to slowly progress into gradual high tone loss with repeated fluctuations bilaterally. In the right or better hearing ear, the fluctuations in hearing acuity presented different features at the high, middle and low tone levels: They were most marked for the low frequencies below $500 \mathrm{cps}$, less for the high frequencies above $4000 \mathrm{cps}$, and least for the middle frequencies of 1000 to $2000 \mathrm{cps}$. This finding seemed to be due to possible difference in vulnerability or in ability to recover in the respective regions of the cochlea.

3. Conspicuous exacerbation of hearing impairment occurred bilaterally during and in a few days after antiluetic therapy with penicillin or erythromycin, being not accompanied with fever or any other general symptoms. The manifestation was interpreted as representing Jarisch-Herxheimer reaction that developed in an atypical fashion. It has been suggested that this reaction will rather be manifested in such atypical form in the antiluetic treatment for late congenital syphilis of the inner ear.

4. Audiometric examinations performed in this case on frequent occasions have demonstrated that amelioration in hypacusis with consequent stabilization of the hearing acuity may be achieved successfully by prolonged, high-dose corticosteroid therapy for this"disease. It has 
been emphasized that, in antiluetic therapy for this condition, concomitant administration of the drug is advisable to prevent aggravation of labyrinthine disorders which may develop in the form of Herxheimer-effect due to the use of antisyphilitics.

A79-1629-25501

\section{晚発性 先天性迷路梅毒の長期観 察の 1 例}

- Hennebert 症候, 聴力変動所見, Herxheimer 反応, 難聴治効所見の検討一

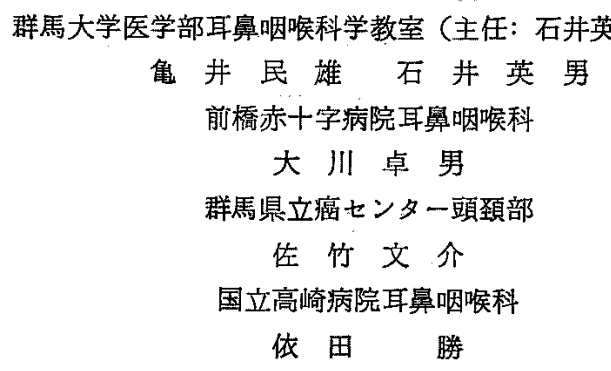

I は しめに

迷路梅毒については古くから論じられてきだ年25)41)

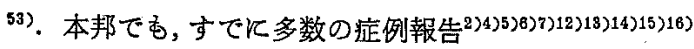
18)20321)ならび飞臨床統計化関する報告(13)89917719) が行わ れている。しかし本疾患は，症状多彩で今日であ依然と して確定診断がしばしば困難であり，難聴の予後も恶く， そのほかてす，検討を要する臨床的課題をな和数多く有 する疾患である ${ }^{53}$. これらが解明汇最す必要とされるす のに，長期観察例での所見の検討があげられる.しかし これまで，加かる報告はきわめてそしい。

筆者らは本稿飞招いて，通算10年の長期観察が行われ た晚発性先天性迷路梅毒 1 症例を報告し，さらにこの症 例にみられた, Hennebert 症候, 著明な聴力变動, 駆梅

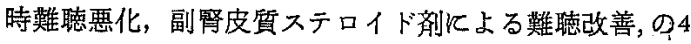
つの主所見をとりあげ，こ机らにつき分析と考察を加え てみた。

\section{II 淀 例}

患者: A. K., 合，1928年6月30日生.

初診: 1963年10月29日 (35盔).

主訴：回転性メマイ発作, 左耳鳴, 左難聴.

家族歷: 両親は健在, ただし㭧者出生以前梅毒飞罹患 し、駆梅療法を受けたことがある。ほかの同胞（弟妹 8

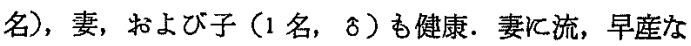
し、な竹両親は血族結婚でない。

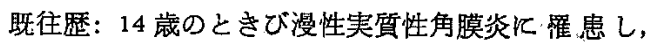
Salvarsan 治療飞て角膜片需を迹し治療した。ほ加恃 別な睡往疾患はない。

現病歷:

11 歳のとき激しい回転性メマイと奬われ，2 日間卧床 したことがあるという。

1962年 4 月（33歳），感署䍜患後 2 力月間喘息様咳濑 が続き，その後間もなくして左耳火蟬鳴様耳鳴が発生し た. 以後この耳鳴が現在まで続いている.10月からはと きどきメマ溌作がるられるようになったこのメマイ 発作はメニエル病の発作江酷仪し，メマイ内容は回転性, 発作持続は $3 \sim 4$ 時間, $メ マ$ 発作時沉悪心, 嘔吐の出 現ならびと左耳鳴の增強が認められた。

さらに翌1963年 4 月 (34歳), 電話での会話に際し左 耳では㯖取が困難なことな自党，また電話の声が左耳に 響いたり，割れて聞こえるなどと感じるようとなった。 よって同年10月29日（35藏）治療を求めて来院した. 初診時所見:

体格中等, 栄独良, 血圧 $124 / 68 \mathrm{mmHg}$, Schellong テスト陰性. 血清反応は RA 陰性, CRP 陰性, ASLO 50 単位以下.

梅毒血清反応は陽性（緒方法 4十，スライド法 2+）。 神経学的検査では第 8 脳神経を除き異常を認めない。 頭蓋X線検查 (Stenvers; Sonnenkalb; Towne, 㑡頭骨 
断層撮影）す異常を認めない，眼科的所見としては両眼 飞角膜片雲（実質性角膜炎後造症）が認められるが，眼 底所見㹥正常である。

耳舅科的視彰所見：鼓膜括よび悬腔所見は正常，一方

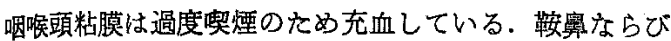
飞 Hutchinson 歯牙は認められない。

酸力検查所見: 图1のごとく左耳に中・低音部でほほ

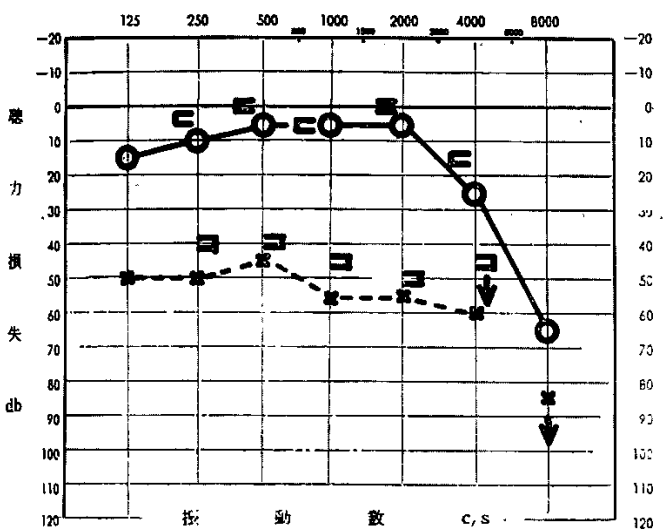

図 1 1963年10月29日（初診時）

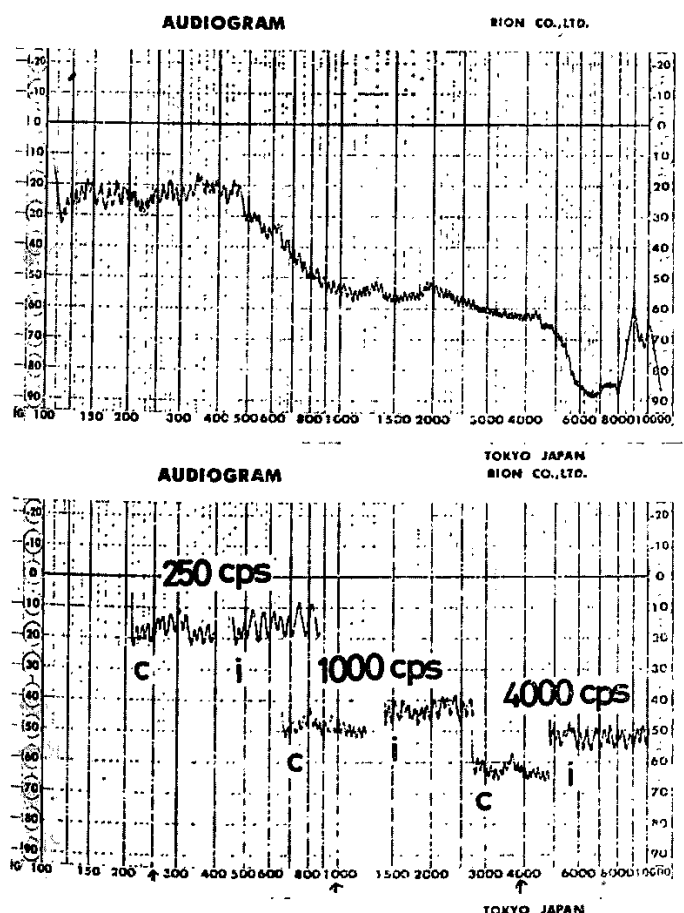

图 21970 年12月14日 (右耳).

下図 $c$ ：持続音， $i$ : 断続音.
$50 \mathrm{~dB}$ の感音性難㴔，また右耳儿も高音急檠型難聴（た だし每目覚)を認める。

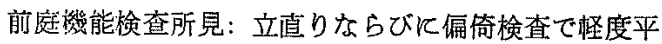
衡障害意管める. 自発眼振㤂よび頭位眼振は陰性, しか 乙頭振り眼振梌登では右向き水平性眼振の誘発を認め る. 冷温交互武験では左耳に半規管嫲㿎が認められる。

治療招上浩経過:

初影後 2 力月間 Balance, Carnigen, Kallikrein, Neuvita の併用投与を行ったところ，蝸牛症状は不变飞 とどまったがメマイ発作は消失し，その後約 6 年間病状 は安定していた。

しかるに1969年10月 2 日（41歳）風邪気味となりく

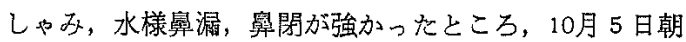
右耳に難聴を自敩(ただし耳鳴随伴なし)，また右耳に外 界の物音がボーンと響くと感じた。十分な睡眠と休鿾を とったところ，10月７日には右鹳聴回復，乙かし10月13 日にらたたび同様の瘁症状が出現し，右難聴も再発した。 以後外来通院飞て施療 (Cercine, Carnigen, Merislon, ATP 投与, および Meylon 毎日竫注)されるも無効で, 右聴力は変動しつつ悪化してきた. 右耳管通気度は良好 であった。

1969年11月 7 日入院.

入院中上記薬郕と併用て Dexamethasone 投与を行っ たところ (4 mg×1 日， $3 \mathrm{mg} \times 2$ 日， $2 \mathrm{mg} \times 4$ 日, $1.5 \mathrm{mg}$ $\times 3$ 日， $1 \mathrm{mg} \times 7$ 日， $0.5 \mathrm{mg} \times 10$ 日， $0.25 \mathrm{mg} \times 3$ 日）， 右聴力は急速に回復した（図 4:（1)）. またアレルギー 性舅炎様症状与消失し，さらに以前からある左耳鳴す軽 快したが，左耳蜼聴の改善はほとんどみられなかった。 12月 8 日退院.

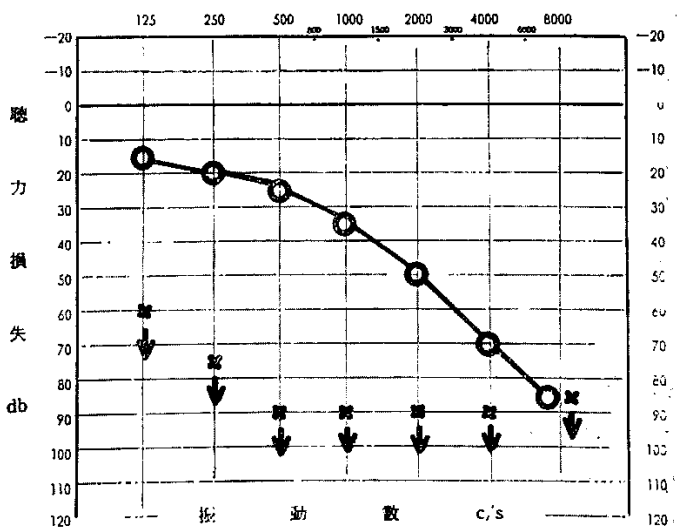

図 3 1973年5月9日(最終診祭時) 

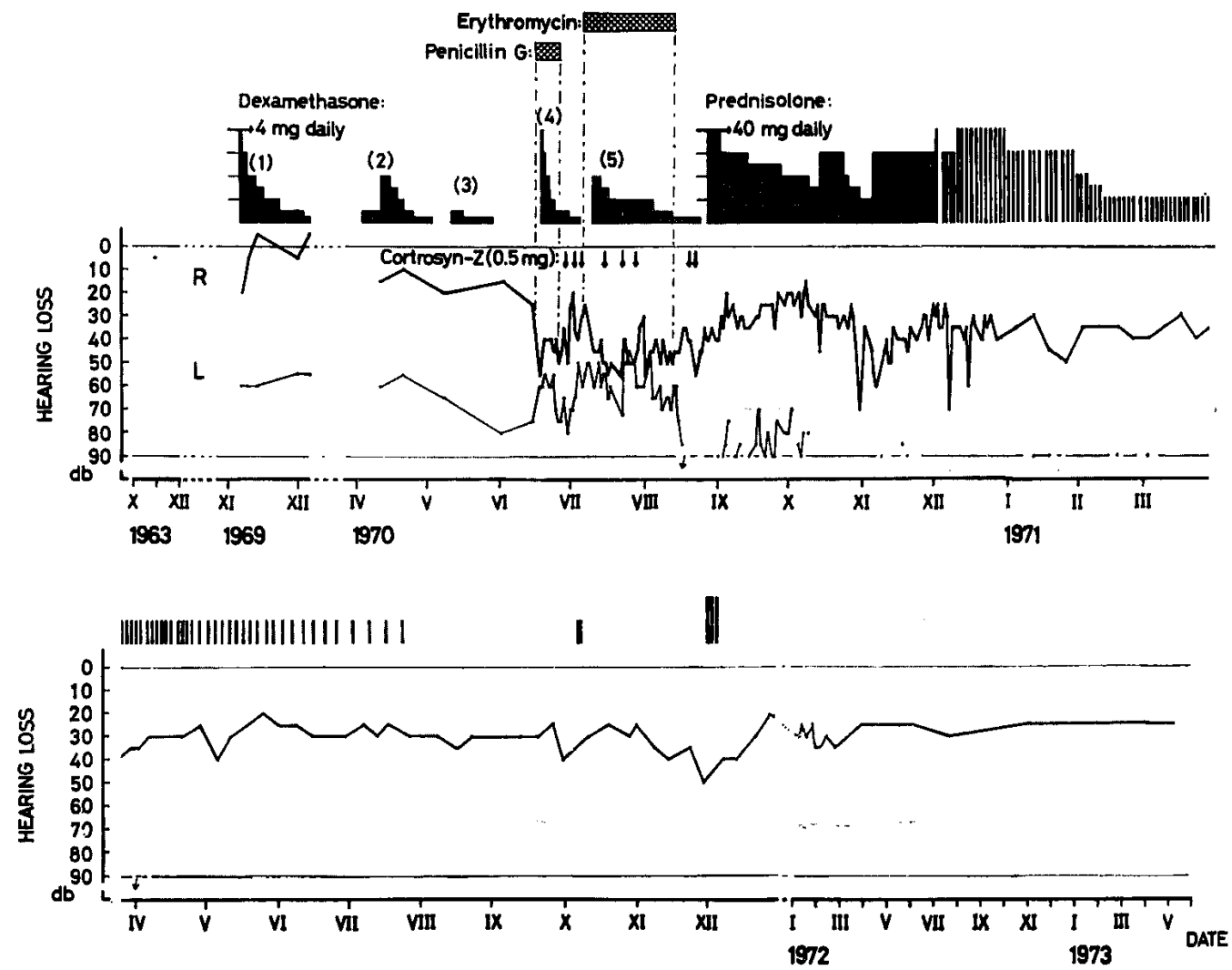

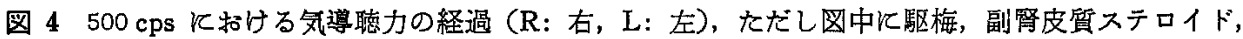
ACTH Kよる治潦歴を附記（下段グラフは上段グラフに続く）.

退院後約 3 力月間内耳症状が小康を保っていたが，之 の後また聴力低下 (両耳) が発来，また軽いメマイすみ られるようとなった.よって1970年4月3日より，通院 Kて再度 Dexamethasone 治療を試みた（図 4: (2), (3)).しかしこのときは投与量が少なかったためか，腑

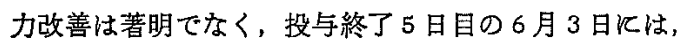
ことに左耳において，著明な聴力低下が発来した。な物 この日, 梅毒血清反応は緒方法で320倍, 凝集法で 2 倍, スライド法で 4 倍と, 緒方法で高值を示していた. その 後 Lucidril, Bellergal の経口投与, 拉よび Nicholinの 毎日筋注を行なうも無効であった。

1970年6月13日（41歳）より12月25日（42歳）まで， 再入院にて治療を行った.

入院中毎日聴力検查を実施してみたところ, 両耳の聴 力が日々激動していることが明らかになった.よって聴 力の安定改善を求め各種の治療が試みられたが，難聴に 奶しなんらかの影響を認めた治療は，駆梅療法，特よび
副腎皮質ステロイド剂や，ACTH 製郕による治療に限 られ，浘かの諸治療では明らかな効果沁認められなかっ た.よって以下，駆梅括よび副腎皮質ステロイド绪によ る治療成䋎を中心に，この時期に招ける本例の難聴の経 過をのべる。

な括，ほか試みられ効果の明らかでなかった諸治祭 はつぎのごとくである：

耳管通気； Meylon 静注; Diamox 潦法 (13日間); 循環堌強剂 (Carnigen, Effortil など), 血管㹡張剂 (Merislon, Kallikrein, Capilan, Nicotinic acid, 塩酸パ パベリンなよ゙)，ビタミン $\mathrm{B}_{1}$ 剂，ATP および Horizon

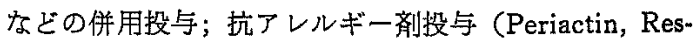
tamin, Hystamin なと); 星状神䅅節遮断 ( 9 回); 消 炎威投与 (Benzyrin, Indomethacin, Kyorinase, Riripen な゙ヒ); 鼓窒内 Dexamethasone 液注入; 腰椎穿刺 によるパンピング(11回)； $\mathrm{O}_{2}$ 吸入；そのほか PerestonN，テラプチク, Nicholin, 高張ぶどう糖液などの静注, 
顷よび Transamin, Juvela, Chondron-S, Cephalantin, Parotin の投与, など.

まず6月16日より駆梅の目的で，油性 Penicillin Gの 1 回60万単位宛每日筋注を開始したところ，6月18日K 右衈力は著明低下し（図 4)，汃新た火右耳鳴（蟬鳴 様) 加発生してきた. よって Jarisch-Herxheimer ない しその類似現象の発来索考光，同日より Penicillin 治療 と併用飞て, Dexamethasone 投与を開始 (初期量 $4 \mathrm{mg}$ ) 日，因 4: (4))，6月20日Kは右聴力がや改善した。 6月25日 Penicillin 治療完了 (計10日間).

しかると6月30日朝加ら左耳鳴大きく，左耳の聴力 低下も著しかった. Dexamethasone は減量中でこの日 $0.5 \mathrm{mg}$ /日と少ないので, Cortrosyn-Z(合成 ACTH 製 剂) $0.5 \mathrm{mg}$ を筋注してみたところ，1 時間後聴力が急 速沉改善した (因 4).

7 月 7 日駆梅第 2 クールの目的で（今回は Penicillin は避け） Erythromycin の経口投与党開始した（1日 $1,200 \mathrm{mg}$ 宛). しかるに 7 月10日ふたたび右聴力の著し 低下が発来したので再度 Dexamethasone の併用投与 開始（初期量 $2 \mathrm{mg} /$ 日，因 4:(5)), しかし今回の Dexamethasone 投与は 1 日量が少なすぎたのか，聴力 改善飞余り有効でない８月13日 Erythromycin 投与 終了(計34日間).

しかるに 8 月 18 日, 今度は左耳飞突然高度難聴が発来 した (図 4).すなわちこの日，患者は朝覚醒時より左耳 て全く䦎こえないことを自覚（ただし耳鳴は不交），聴 検成精では左耳柱全周波数沈わたり scale out である. 各種の強力な難聴治療を試みるも無効，その後さらに右 難聴も悪化の傾向を示したので，今度は Prednisolone の大量長期投与を行う計画を立て，8月27日より同剂の 投与を四始した(ます $40 \mathrm{mg} \times 6$ 日投与，つづいて 30 $\mathrm{mg} \times 12$ 日，25 mg×14日，20 mg $\times 20$ 日投与). その結果 右㯖力次次第飞改善し, scale out であった左德力も， 僅かであるが出没するようになった（図 4)。しかし10月 9日より Prednisolone $15 \mathrm{mg}$ /日飞減量したところ， 10月13日らたたび両耳聴力が悪化（左耳てはふたたび. scale out), よってふたたび Prednisolone を1日 30 mg K增量した. その後も Prednisolone 減量が $20 \mathrm{mg}$ / 日以下飞拈よよ右聴力が㦞化することが明らかとなっ たので，11月6日よりすう一度 $30 \mathrm{mg} /$ 日増量し，以 後11月30日まで同量を維持, その結果右聴力が徐々江回 復してきた.

な视副腎皮質ステロイド郕長期投与による副作用には
始終注意し, 頻回飞血王測定, 尿糖倹查, 血糖定量, 血 中電解啠定量; 尿中 $17 \mathrm{KS} \cdot 17 \mathrm{KGS}$ 定量などが行われ たが, 軽度 moon face の出現を除き, 幸い異常は認め られなかった。

12月1日副瞥皮質ステロイド離脱の目的で，Prednisolone 投与を間歇大量投与飞切り替光た (図 4).この 投与法切り替光の初期に怡聴力の変趿が大きかった が，その後次第に落ち付いてきた。 12 月 25 日退院 (42 歳).

以後通院飞て Prednisolone 1 日 $30 \mathrm{mg}$ 宛隔日投与 と, Horizon, Primperan, Capilan, Carnigen, Juvela, ピタミン K, Kyorinase など適宜内服にて経過観察を 行ったところ，右聴力は次第に安定してきた.よって Prednisolone 徐々K減量し，1971年 7月28日 (43葴), 約11力月Kわたる Prednisolone 投与飞終止等を打った。

その後他凨す徐々飞減量し，1972年 2 月 1 日よりは全 投薬を打ち切った，その後さら飞1973年5月9日(44歳) まで聴力の経過を追求した。最終診察時聴力所見は図 3 飞示すごとくである。（な拈1976年 1 月患者からの電話 連絡によれば，右聴力はその後も変りないことのことで ある)

III 考 察

主要所見の検討飞先立ち，まず本例の診断を確認した い. 本例は初診時メ二エル病との鑑別が困難であった か，最終的飞悗発性先天性迷路梅毒と診断された。診 断の根拠はつぎのごとくである.

1. 梅毒反応陽性（表 1)

本例は梅毒血清反応 応 (凝集, ガラス板) とも長期にわたり常に陽性であ り，加抗体価が高值を示したこと(緒方法40倍以上， 凝集法 4 倍以上，ガラス板法 4 倍以上)，またさらに梅 毒浮対し特異性が高いといわれる TPHA (treponema pallidum hemagglutination test）加陽性であったこ とより, 生物学的偈陽性反応例 ${ }^{10349)}$ (biological false positive reaction: BFP) ではないと考えられる. 慢性 BFP 呈しうる瀨，エリテマトーデス，マラリヤも本 例で認められない。

2. 実質性角膜炎の既往 (14葴)

3. Hennebert 症候陽性

この所見については後述するが，本例でこれが1970年 8月 8 日 ( 42 歳) より約 1 年間沉わたり，両耳において 観祭された。本例で本症候は，最初通気時眼が動くとい うことより気付かれた。本症候は先天性迷路梅毒保特有

$12-101$ 
表 1 梅毒反応検査成繶

\begin{tabular}{|c|c|c|c|c|c|c|c|c|c|c|c|c|c|c|c|c|c|c|}
\hline \multirow{2}{*}{\multicolumn{2}{|c|}{$\begin{array}{l}\text { 敛查䒠施日 } \\
\text { 梅毒反虑 }\end{array}$}} & \multirow{2}{*}{\multicolumn{3}{|c|}{ 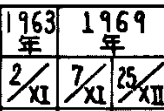 }} & \multicolumn{14}{|c|}{ 1970年 } \\
\hline & & & & & $3 / \pi$ & 6/12 & 5/ & $22 / 6$ & $28 \%$ & $7 / x$ & $19 / x$ & $30 / x$ & 16/x]? & $25 / 10$ & $4 / \times n$ & $11 / x$ & $18 \times 1$ & $23 \times 1$ \\
\hline \multirow{4}{*}{ 血 } & 緒方法 & $f(t)$ & (t) & $\begin{array}{r}40 \\
\text { 倍 }\end{array}$ & $\begin{array}{r}320 \\
\text { 信 }\end{array}$ & 10 & 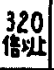 & & & & & & 40 & & & & 40 & \\
\hline & 凝集法 & & (t) & $2_{\text {传 }}$ & $\tau_{\text {借 }}$ & $4_{\text {倍 }}$ & & & & & & & ${ }^{8}$ 借 & & & & 4 & \\
\hline & スライド法 & $2(t)$ & $(t)$ & & 4 传 & $4_{t}$ & $1_{\text {佮 }}$ & & & & & & $2_{\text {ft: }}$ & & & & $2_{\text {借 }}$ & \\
\hline & TPHA法 & & & & & & & & & & & & 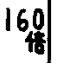 & & & & $\begin{array}{r}160 \\
\text { 话 }\end{array}$ & \\
\hline \multirow{4}{*}{$\begin{array}{l}\text { 骨直 } \\
\text { 液 }\end{array}$} & 緒方法 & & & & & & & $\leftrightarrow$ & $\leftrightarrow$ & $(\rightarrow)$ & 年 & $\begin{array}{l}10 \\
\text { 倍 } \\
\end{array}$ & & 80 & $\leftrightarrow$ & $\leftrightarrow$ & $\begin{array}{l}10 \\
\text { ff }\end{array}$ & $\leftrightarrow$ \\
\hline & 凝柴法 & & & & & & & $\leftrightarrow$ & $\leftrightarrow$ & $\leftrightarrow$ & $\rightarrow$ & $\leftrightarrow$ & & & $(-)$ & $\leftrightarrow$ & $\leftrightarrow$ & $(-)$ \\
\hline & スライト法 & & & & & & & & & & $(\rightarrow)$ & & & & & & & \\
\hline & TPHA法 & & & & & & & $\begin{array}{r}10 \\
\text { f. }\end{array}$ & $\begin{array}{c}10 \\
\text { 借 }\end{array}$ & 160 & $(\rightarrow)$ & $\leftrightarrow$ & & $\rightarrow$ & $\leftrightarrow$ & $\rightarrow$ & $\mapsto$ & \\
\hline
\end{tabular}

であるが24(35)41347)53)，稀に後天性迷路梅毒25)，メ二エル

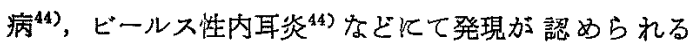
という.しかし本例では梅毒反応陽性，実質性角膜炎 (十), 両親の梅毒 (十)であり, 本例で本症候が先天性 迷路梅毒の一症状として発来したことに疑念の余地はな いと考劣られる.

\section{4. 晚期発症}

晚発性先天性梅毒の発症は学童期 $(7 \sim 8$ 歳)上り20 歳まで，ときにそれ以後とされる29353. 本例は乳幼児期 梅毒症状を欠き, 発症は11歳で回転性メマイ，14歳で実 質性角膜炎，33歳で左耳鳴等々である.したがって本例 で早期先天梅毒，幼児再発梅毒は否定され，晚発性先天 性梅毒之診断される。

\section{5. 内耳障害の存在}

Hennebert症候は内耳娈害の確実な証拠であるが，つ ざの所見る本例で内耳障害の存在を裹付けている.

i) 自覚的聴覚過敏の存在

ii）他覚的補充現象陽性……とえば，1970年 7 月 7 日 SISI-score (Jerger 原法) は, 500, 1, 000, 2, 000 $\mathrm{Hz}$ の各周波数で右耳でそれぞれ 35，100，100\%，左耳 でそれぞれ 80，100，100\%であった.また1970年12月 14日自記オージオメトリー（右耳）で，持続音化て著明 な振巾縮小を認めた（図 2，上）.

iii) Jerger II 型 (因 $2, 下)$

しかしながら本例で，障害が内耳のみに限局していた か否かは即断できない。一般に迷路梅毒は Meningo-

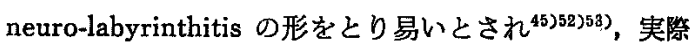
本例で，脳脊䯣液梅毒反忘はとき陽性所見を呈してい る.したがって本例で, Meningo-neuritisが併存してい た可能性は否定できない，しかし脳脊䯣液所見はとれ以 外には正常であり，また症候的にも神経学的検查ならび に自発・誘発眼振检查で中枢障害を示す所見を認めず, 聴力検查です後迷路障害を示す所見はなく，したがって 本例で Meningo-neuritis は存在したとしても，顕性で はなかったと考党られる。

以下本例飞特いて諗められた主要所見につき，検討と 考察を加える.

\section{A. Hennebert 症侯}

本症候は正常な鼓膜を有する迷路瘦孔なき症例におい て，外耳道の加王または減王により瘦孔症状(眼振出現) が認められるもので, 最初 Hennebert (1911) ${ }^{33)}$ が氖载, 以来先天性梅毒にほぼ固有とされてきている現象であ る 24)95)41)47)53). したがってひとたび本症候が認められれ ほ，その診断的意義はきわめて大きい.

しかしながら本症候は，報告者により発現率に大きな 相遀が認められ，そのためその臨床的意義が，さまざま に評価されてきた現象であある。たと充ば Perlman ら $(1952)^{47)}$ は，挽発性先天性迷路梅毒11例中 8 例(約72\%) に本症候を認め，この症候の診断的意義を高く評価した が，これに対し Gstaltner $(1960)^{28)}$ は，本症侯は先天性 迷路梅毒の約 $2 \%$ 証明されるにすぎないと批評してい る.とりわけ本邦比招いて本症候の報告にそしく，これ 
までずかに城所 (1931) が，先天性迷路梅毒13例中の 几例飞これがうたがわれる症例が経験されたと述べてい るとすぎい，小松崎ら(1963)93 22例中全例にこれを 証めず，従来より有名な本症侯を，Augenzittern（眼の チラッキ)を眼振とみあやまってきた可能性むなしとし ないと批評している。

本症候の発現率がこのよう飞報告者により大きく異な る最大の理由は，一般江本症候で認められる眼振が，ふ つろの半規管掼孔症状の場合と異なり，多くは瞬時的 (1-2 秒) な微弱な眼振 ( 2,3 打) として出現し47), 方 向も症例によりさまざまで22224)，したがってともすれば 見逃され易い性質のあのである点化あると考えられる.

筆者らの症例での所見はつぎのごとくである。

すなわち，右耳では外耳道加圧 (Politzer 球使用) ま たは耳管通気時に，反時計方向回旋性要素を帯びた左下 眼臉向き眼振が数打出現し（同時に瞬時的メマイを随 (半), 外耳道減圧では小さな時計方向回旋性眼振が出現 した. また左耳では，外耳道加圧または耳管通気により 時計方向回旋性要素を帯びた小さな下眼險向き眼振が出 現し，こ机に対し外耳道減圧ては, 明らかな眼振は誘発 されなかった。

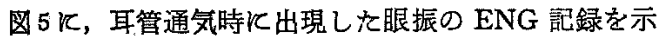
す（ただし ENG では眼振の回旋性成分は記録されない ことて注意!).

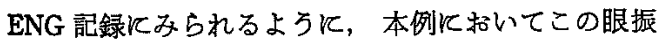
は, 従来の報告 ${ }^{24) 27}$ ) C一致し持続時間1-2秒, 眼振数 $1-3$ 打である.また ENG 記録より明らかなよろと，眼振は 楼徐相，念速相の両成分を有し，単なる眼のチラッキ (この場合は眼運動に緩徐相成分を欠く)では決してな h.

さて本症候の成立について，古くは種々仮説的な説明

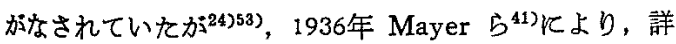
梱な病理組織知見飞もとずく考察が行われた. 彼らによ れ活本症候の成立は，つぎの 3 過程で可能という。すな わち，1. 周囲からの迷路骨包への骨䯣炎性侵蝕，2.ゴ 么睡炎性侵蝕飞上る骨半規管内面の骨䯣腔への突出ない

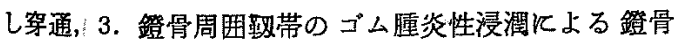
の可勘性の異常増大である.これらのうち2.唯する られ易く，Mayer らはその際の眼振発現機転を，骨䯣 は王縮性があるため，この病変炕上り鐙骨は内方への移

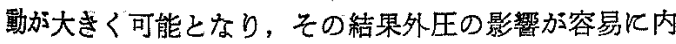
耳飞站よび易くなるためと説明している。

篚者らの症例浡いて，誘発された眼振が主として回
旋性垂直性で，水平性成分には乏しかったことは，本例 に乱いて外圧の作用が主として垂直半規管系に墈きこ れに対し水平半規管へは影響がすくなかったことを意味 している.このことは篚者らの症例沉和ける本症候の成 立が，多分水平半規管経由の圧介達に上ったものではな くMayer 5の2. 加3. の型, すなわち前庭空経由の圧 介達彷よったあのであるろことを示唆している．現在多 〈の報告者 ${ }^{33}$ >44)47〉は，些細な点は别とし，本症候の発現 が前庭空経由の圧介達によるとみなす点で，一致してい る.これk関連し Perlman 5 (1952) ${ }^{47)}$ は，一般に耳小 骨連鎖は外耳道加圧よりは陰圧でより容易飞動かされ易 く，したがって本症候の発現も陽圧負荷よりも除王負荷 時火みられ易いと述へている。しかし笔者らの症例はこ れКは該当しない，迷路梅毒の内耳病变の複雑性 ${ }^{252413533}$

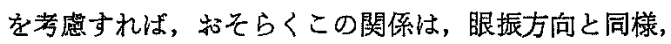
症例侣上り種々と考えられる。

いずれにしても Hennebert 症候は，本邦に执いて， もし存在してすきわめて稀な現象とみなされてきたすの である．しかし筆者らの症例恃本症侯関する従来の諸

a
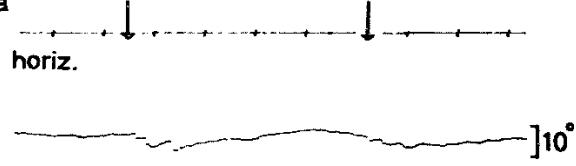

b

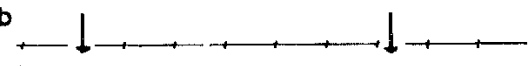

horiz.
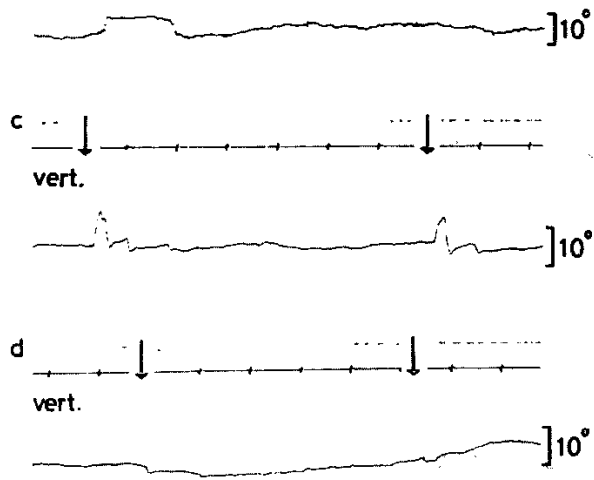

$\overline{1 \sec }$

図 5 1970年8月29日 $\mathrm{ENG}(\mathrm{TC}=0.6$ 秒). 右通 気で左向き(a) 蛙よび下向き (c) 飞眼振出現, 左通気ては水平方向隹眼振誘発なく(b), 下 向き(d) 飞小眼振出現 ( $\downarrow$ は通気開始特点). 
記述を確認するあのであり，さらに本症候が単に診断的 意義をるつにとどまらず，先天性迷路梅毒の臨床病態生 理にとっても，きわめて興味澡い現象であることを示す あのである。

B. 聴力変動所見

いわゆる聴力変動型迷路梅毒佀関し，発症が晩発性先 天性迷路梅毒《多いこと年31)35337)46>47)，発症病理として 梅毒性迷路骨包骨炎の結果としてての二次的内リンパ水

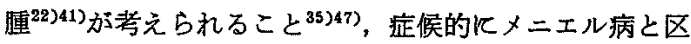

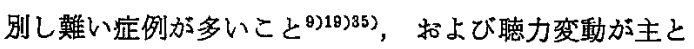
して低音部に生じること早95)，などの諸点が知られてき ている.しかしこれまで，聴力変動の詳しい様相につい ての報告はほとんどなく，筆者らの症例はこの点を若干 補足しうると考劣られる。

因6に，本例に和いて10年間に実施された合計 233 回 に括よ゙気導聴力検查成績を，重和合せ図として示す この図は本例の聴力変動の様相に関し，つぎの 2 点を明 らかにしている.すなわち，

1. 聴力障害は両耳に和いて, 变動をくり返しつつ, 次第に高音漸傾型へと移行している。（ただし 左耳はあ る時点で, 突発的飞全珁となった)

2. 右耳に於いて咕力変動は, 高, 中, 低の3音域で, その様相を異にしている.すなわち右耳聴力変動は, 500 $\mathrm{Hz}$ 以下低音部で最も著明かつ頻繁で方り，ついで4,000 $\mathrm{Hz}$ 以上高音部で著明，これに対し $1,000-2,000 \mathrm{~Hz} の$ 中音部では，聴力変動は比較的軽度であった。(なおこ の関係は，左耳では難聴高度なため明らかにできなかっ た)
さて，上の所見 1. Kついては，山根ら (1974) 同様な所見を呈した 1 例を報告している.したがってこ れは変動性㯖力障害例がたどる 1 つの経過を示す所見と 考えられる. 所晃 2. Kついては，ほかに同様症例の報 告がなく解秎困難であるが，あるいはこれは，一般に螖 牛の高，中，低音域任相当与る各部分が，受傷性ないし 回復性の面でそれぞれある程度の特異性を有することを 意味する所見ではないかと考えられる、蝸牛のかかる3 分が何らかの部位的受傷特性を有することは，これまで 同一症例で証明された例はないと思われるが，たと光ば 中耳炎性ないし中毒性内耳障害で高音障害が生じ易く， 造伝性難聴で中音障害がみられ易く，また内リンパ水茞 で低音障害が発来するなどの臨床的諸事実 ${ }^{382}$ よ，十分 推定されうる事柄といえる.

C. 駆梅による難聴悪化（非典型的 Jarisch-Herxheimer 反応)

本例の治療にあたり筆者らが最す困惑した点は，駆梅 時再三にわたり，著明な聴力悪化が発来したことであ る. 要的すれば, Penicillin 治療開始後 2 日目右耳で， 同治療終了後 5 日目に左耳て，また Erythromycin 治療 では，投与開始後 3 日目に右耳で，それぞれ夋激加著 明な聴力低下が発来し，その後 Erythromycin 投与中左 耳聴力はきわめて不安定であり，同㶡投与終了後 5 日目 には，左耳はついに全整となるにいたった。これら薬郕 の内耳毒性山知られて扣らず，したがってこれは，駆梅 自体の副作用であったと考えられる.

ではこれは，Jarisch-Herxheimer 反応であったので あろうか。

R: $\quad$ cPs $125 \quad 250 \quad 500 \quad 1000 \quad 2000 \quad 4000 \quad 8000$

L: $\begin{array}{llllll}125 & 250 & 500 & 1000 & 2000 \quad 4000 & 8000\end{array}$

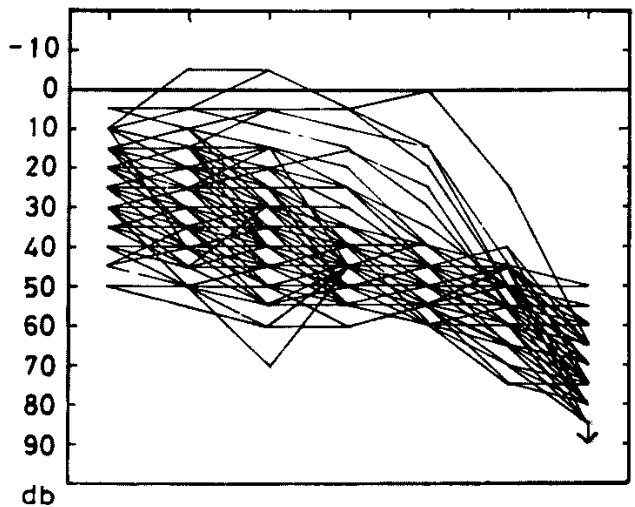

図 6 計 233 回の気望聴力検查成結重畳図 (R: 右, L: 左) 
駆梅の剧作用として, 神経再発症 (Neurorezidive) と Jarisch-Herxheimer 反応とが知られている ${ }^{53)}$.このう ち前者は，Salvarsan の不完全治療汇上る再発（神経障 害)で，その発現時期は駆梅後 6-8 力月とされる23). したがってこれには，本例杜明らか机該当しない，

これに対して Jarisch-Herxheimer 反応は，駆梅自体 Kもとずく Provokationsnebenwirkung ${ }^{532}$ で，駆梅の 種類を問わずあらわれうるものであり，その発現機序は， 余り飞も急激な梅毒トレポネーマの崩壊，竦よびその結 果としての大量の Endotoxine の遊離にある ${ }^{233253}$ と解さ れているものである.したがって本反応の発現は早く治 甞開始後24時間以内であり ${ }^{34)}$ ，症状として発 熱（平均 $1.5^{\circ} \mathrm{C}$ 上昇， 24 時間以内K下熱開始)，悪感，筋肉筋， 頭痛, 心悸六進, 呼吸促迫, 白血球增多, 血管讼張, 怪 度血圧低下などの全身反応を認め ${ }^{34)}$ ，さらに急性脳浮旡

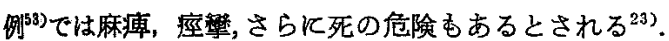
O. Beck $(1926)^{25}$ ) $\mathrm{C}$ 上れば本反応としての内耳症状（耳 鳴, 難㯖, 前庭症状）は, 全 Jarisch-Herxheimer 反応 例の $25 \%$ K認め，発現時期は Salvarsan 注射後数時間 ないし24時間，まれれ 2 日後までであったという。

しかるに筆者らの症例で駆梅の副作用が考光られた難 㯖覀化は，発現か駆梅中および駆梅後 5 日目までの各 種の時期と拓そく，またほ加何らの全身症状す伴われ なかった点ですさなくとも典型的な Jarisch-Herxheimer 反応といえるものではない，しかしこれは，筆者 らの見解彷よば本反応を否定するあのではなく，本例 で本反応が非典型的な形で発現したことが考えられる。 さら筆者らの見解炕上れば，実は一般治発性先天性 迷路梅毒行怙いて，本反応はむしるこのような形で発現 し易いであろろことが推椡される。これらの理由はつぎ のごとくである.

1. Jarisch-Herxheimer 反応山, 一次梅毒の約 $50 \%$, 二次梅毒の $90 \%$ ，早期潜伏梅毒の $25 \%$ に打いて発来する といわれる ${ }^{34)}$. しかし晩発性先天性梅毒では，この発現 率柱明らかでない，乙かし筆者らか，婏発性先天性迷路 梅毒に限って文献にあらわれた多数例を検討してみたと ころでは，本症に括いては典型的な本反応発現例にはは とんど遭遇しない．これに対し，筆者らの症例と同㥞 飞, 駆梅の各種の時期に内耳症状か悪化している例飞 は，ときとして遭遇するすすなわちすくなくとも本症 にあっては，駆梅の副作用は和こったとしても，典型的 な Jarisch-Herxheimer 反応の形で忏発来しないことが

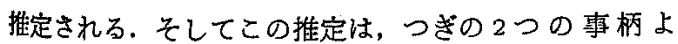

り，十分你根迈を存する香ののようにみえる。

2. 喼登性先天性梅毒火括いて，はたして概毒卜レポ ネーマが検出されるか牥久しく興味ある課题であった が，近年にいたりこれが検出が相ついでなされた。すな

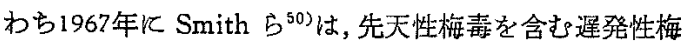

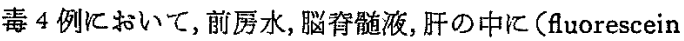
antibody technique)，炑同年 Goldman $5^{28)}$ は晚発

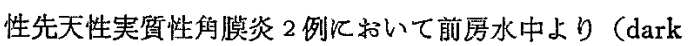
field 法), さら飞1969年 Mack 方 ${ }^{40}$ は, 晚発性先天性 迷路梅慧の 1 剖検例炕て迷路骨包中K（Krajian silver 法)，それそれ少数の梅毒トレポネーマを証明している. 乙か子 Goldman らの症例拈よび Mack らの症例は, 病原体が検出される以前すでと Penicillin を舍む強力な 駆梅が実施されていた症例である. Smith ら (1968) $)^{51)}$ もさらK，後期梅毒が Penicillin 治療沉强い抵抗性を示 し、梅毒トレポネーマが生存しつづけることを証明して いる.これらの諸事実は，明ら加に，一般に晩発性先天 性迷路梅毒儿沏いて，病原体は少数であろらが実際存 在すること，またそれが強力な駆梅抵抗性を有している ことを示している.としてさらにこのことは，本症の駆

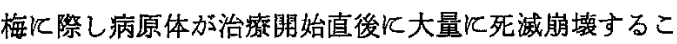
とはなく、むしろ駆梅中の種々な時期涉数宛死堿する 可能性が大きいことを示唆している.このことより,一 般飞本症飞括いて Jarisch-Herxheimer 反忘は, 発現時 期の点で，河梅開始直後発来という典型的な形はとり難 々，むしろ筆者らの症例のごとく，駆梅中の種々な時点 飞据いて生じ易いことが考えられる。

3. 梅毒は過敏 (アレルギー) と免度の複雑な混合の

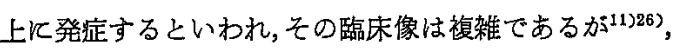
梅毒炎自体は，梅毒トレポネーマの抗原性を有する endotoxink対する組織の過敏反応と理解されている ${ }^{30)}$. しかるに梅毒炎がこのようと解积される以上，駆梅は当 然，一時的飞せよ，過敏な組織飞梅毒炎の增悪を招きう るといえる.なぜな，駆梅は必然的に，病原体の殺隇 により endotoxin の遊離をむたらすからである。そして このことが，Jarisch-Herxheimer 反応の本熊に 棌かな らないと考光られる. また, あし組織, 器官がすで強 い免疫を獲得していれば，そこでは本反応は生じないて あらうことも考兄られる。ささ晚発性先天性迷路梅毒 は，一般沉先天性梅毒がとりうる最後の症状であること が知られている31)，そしてこれが発症時期《は，ふつう ほかの組織，器官は，もはや活性の梅毒症状を呈さな い，たとえは，先天性梅毒のすう一つの好発症状である 


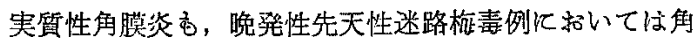

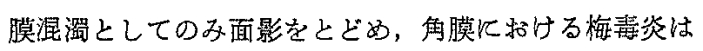
すで治窟しているのがらつろである.すなわち本症に 扔いては，この時期内耳がはとんど噍一の過敏器官であ り，これに対しほ和の組織器官は，すて飞病原体の endotoxin 飞対し強い獲得免疫を有していると考兄られ る.このことは明らかと，駆梅の副作用が本症と括いて， 内耳のみに限定され易いであろうことを意味てしいる。

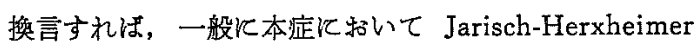
反応は，発現内容の点で全身症状は呈し難く，筆者 $5 の$ 症例のごとく，主として内耳症状の恐化という形で発来 し易いことが考えられる。

さて，これまで晚発性先天性迷路梅毒の駆梅の副作用 については，文献的に明確な記載を欠いてきたといえ る.しかるに以上の考察は，この点を蛹い，本症に括い て Jarisch-Herxheimer 反応が，一般飞非典型的飞, 遷 延され (発現時期), 限定された形 (内耳症状) で発 来 する可能性の大きいことを指摘するすのである. そして このことが本庭の駆梅の実際澺味するところは, きわ めて大きいと思われる.

これまで本症炕招ける難聴の駆梅の予後は，ことさら 覀いとされてきた，この理由の1つは，実はかかる非典 型的 Jarisch-Herxheimer 反応の結果としての, 内耳病

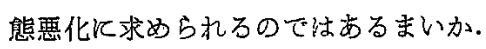

D. 副堅皮質ステロイド郕の難聴改善効果.

迷路梅毒江よる難聴の駆梅儿上る治療予後は, きわめ て早期 (発症後 4 週以内 $)^{399}$ の治療例を除き, これまで一

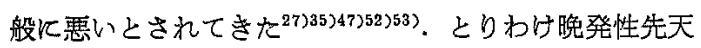

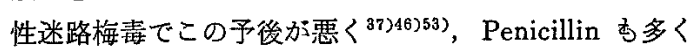

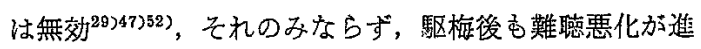
行する例がすくなくないことが知られている31/47〉。

しかしながら他方に招いて，1952年 Perlman $5^{47) か ゙ ， ~}$ 晚発性先天性迷路梅毒例保駆梅 (Penicillin) と ACTH の併用治療を武み成功して以来(5 例中 3 例で難腎改善),

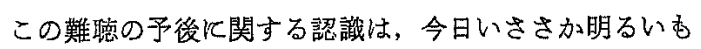
のに变ってきているようにみえる，その後の報告では， 主として副婜皮質ステロイド绪が用いられているが，こ れまで Morton ${ }^{42)}$, Murphy $5^{13)}$, Hahn $5^{31)}$, Karmody $b^{35)}$, Patterson $^{46)}, \operatorname{Kerr} 5^{36337)}$, 江上 $5^{11}$, Willcox $b^{54)}$, Hendershot ${ }^{32)}$ ，Nadol $5^{45)}$ の報告があり，長期投与例，

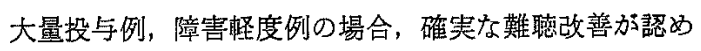
られている31335)45546). たと光ば Morton は本症 4 例䎲 Prednisolone の少量短期投与 (1日10 $\mathrm{mg} \times 3$ 日，以後
1 日 $5 \mathrm{mg}$ ，全 3 週）を行い難德飞対する効果を認めなか ったが, Hahn ら㹥本定19例飞 Prednisone の大量長期 投与 (1 日 $30 \mathrm{mg} \times 1$ 週, 1 日 $20 \mathrm{mg} \times 3$ 週, 以後每月 1 日量 $2.5 \mathrm{mg}$ 宛減量)を行い，10 例行純音または語音德 力の改善を, また全例行聴力の安定化を認めた. まを最 近 Nadol 5 (1975) ${ }^{45}$ は, 自験招よび文献的考察にもと

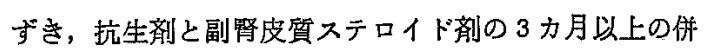
用投与をすすめ，これとよって約半数例飞路いて梅毒性 難聴の改善が望めるとしている. 多くの報告者は副腎皮 翼ステロイド剂の治効を，その強力な抗炎作用，抗免度 反応作用汯めている ${ }^{87488}$.

さで，筆者らの今回の報告は，1症例での治験成續に 関するすのてはあるが，頻回な滤力検查にもとずき，副 督皮質ステロイド剤の治効を確実に証明したものといえ る. 筆者らの症例机いて，本剂は主として右耳有效 で, Dexamethasone では 1 日 $2 \mathrm{mg}$ 以上投与の場合, また Prednisolone では 1 日 $20 \mathrm{mg}$ 以上投与の場合, 確 実に聴力改善がもたらされた。ただし短期投与では, 後 にらたたび聴力低下が発来し，これに対しPrednisolone の11カ月に蛒よぶ長期投与で, 右耳聴力は安定した。他 方障害高度な左耳では，本剂は十分奏效せず，ついに全

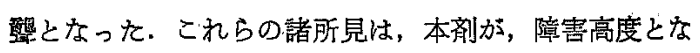
らざるうちに，長期大軖投与の計画のもとに使用されな ければならないことを物語っているといえる。

筆者らの症例飞和けるもうひとつの見逃せない治験成

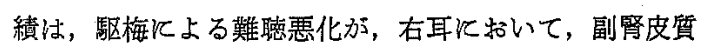
ステロイド剂により改善された事実であろろ. 駆梅と本 剤の併用に関し，まだ諸家の意見は一致していない。し かしすでに考察してきたように，駆梅の副作用としての 内耳病態悪化は，ことに晚発性先天性迷路梅毒では，駆 梅の全期間にわたり生じる可能性があり，かつその本態 が過钽反応の増悪と理解されるものである以上，駆㽦に 際しその全期間を通し，十分な副腎皮留ステロイドが併 用投与されることは，副作用発現防止の意味に和いて， きわめて望まれる処置と考劣なければならない，そして

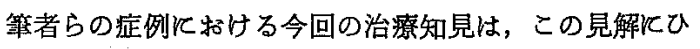
とつの支持を与えるものと考えられる。

以上筆者らは，自験招よび文献的考察にもとずき，堍 発性先天性迷路梅毒儿招いては，副腎皮質ステロイド渢 の長期大量投与が試みられるべきてあること, また，本 症の駆梅際しては，本㓮の併用投与がなされるべきこ と,の 2 点を主張するむのである. ただし本剤の長期使 用にあたっては, その使用禁忌, 副作用などに, 十分な 
臨床上の眍慮がなされなければならないことがここに 付記されなければならない，

\section{Vまとめ}

長期短察（通算10年）が行われた晩発性先天性迷路梅

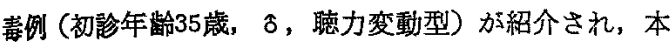
例て観察された特哄な所見につき，分析と考察が加えら れた.

1. 本例で Hennebert 症候が, 両耳儿和いて約 1 年 間にわたり認められた。誘発された眼振は持続1-2秒， 眼振数 1-3 打で, 主として回旋性垂直性化出現した. 発現機序としては，眼振所見（方向）ょり，前庭空経由 の压介達化すとずくことが推論された。

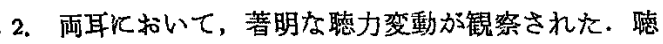
力障害は変動をくり返しつつ, 次第に高音溸傾型へ之移 行していく傾向を示した. また右耳に招いて，聴力変動 出高, 中, 低の 3 音域で, その椂相を異にしていた。 こ れれ蝸牛のこれら 3 音域に相当する各部分において，受 复性ないし回復性飞相䧺があるためと推察された。

3. 駆梅 (PE，EM) 飞際し, 駆梅中または駆梅後数 日までの種々な時期に，全身症状の随伴なしに，著明な 犆力悪化が発来した.これは非典型的な形で発現した Jarisch-Herxheimer 反応と解釈され，その理由が説明 された. また一般に本症で本反応が，加る形にて発現 し易いであるうことが考祭された。

4. 剧堅皮質ステロイドの長期大量投与により，本症

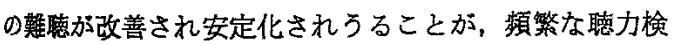
查成績にもとずき明らかにされたままた駆梅に際して 仕, 内耳の病態悪化を防くため, 本剂の併用投与が望ま しいことが強調された。

\section{文献}

1）江上徽也他：血清梅盇反応陽性「ぬまい」症例の臨

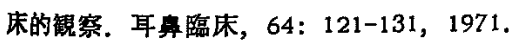

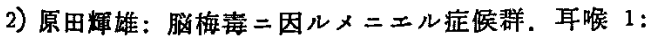
1054-1055, 1928.

3）細田忠四郎: 果シテ梅毒患者二八骨導短縮 乎、日耳鲜，23：262-273，1917。

4) 加藤寅二郎他：梅毒性脳萎縮费者の頭部打授後の前 远症状飞っいて。耳展，7：248-252，1964.

5) 勝木保次: 聴器梅毒,一症例。日耳率，38：1474, 1932.

6）葛目玄吉: 梅毒性内耳炎二試ミタルスキフト，エリ 互氏「サルウルサン」㞠法。日耳楀，23：273-277，
1917.

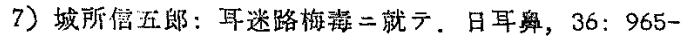
1043, 1069-1106, 1931.

8）城所信五郎他：梅毒二因ル聴器弈害二就テ.日耳率, 39: 2175-2202, 1933.

9）小松渏䉆他：小わゆる迷路梅毒の臨休的考察.耳喉, 35: 275-285, 1963.

10）蝻本雅彦他：実地医家のための梅毒の診断々沿瘵. 金原出肘, 東京, 1971.

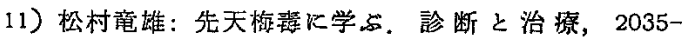
2037, 1973.

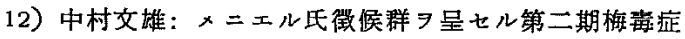
例. 耳喉, 6:766-773, 1933.

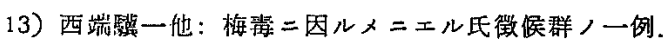
耳喉，1: 1463-1473，1928.

14）野本科一郎：迷路梅毒のマラリヤ療法。耳倨，20: 204-207, 1948.

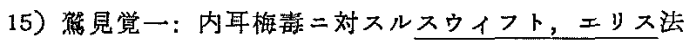

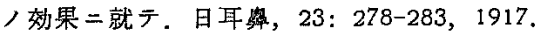

16) 田中敬明他：迷路梅毒のペニシリン発坥(マラリア) 併用療法比就て。耳耳鼻，55：896-902，1952。

17)立木 孝：先天性迷路梅毒症例. 耳喉，30：965$969,1958$.

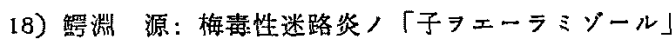
治験。日耳鼻, 28: 110-112, 1926.

19）渡辺勤他：メ二エル症候型迷路梅毒の臨床的観 察. 日耳堅, 66: 923-933, 1963.

20）山室重遠：迷路梅翼の 2 例. 耳喉，22：193-198, 1950.

21）山根 仁他：先天性梅毒の是われる症例にみた聴力 の変動. Audiology, Japan 17: 533-534, 1974.

22) Andersen, H.C.: Ein Fall von kongenitalem syphilitischem Ohrenleiden mit klinischer und pathologischer Untersuchung. Acta oto-laryng. (Stockh.) 25: 37-50, 1937.

23) Beck, K. : Intoxikationen. In: Handbuch der Hals-Nasen-Ohren-Heilkunde, hrsg. von A. Denker u. O. Kahler, Band 6/Teil 1: 828-842, Springer, Berlin, 1926.

24) Beck, O. Syphilis des Ohres und seiner zentralen Bahnen. In: Handbuch der Hals-Nasen-OhrenHeilkunde, hrsg. von A. Denker u. O. Kahler, Band 7/Teil 2: 650-677, Springer, Berlin, 1926. 
25) Beck, O.: Allgemeine Pathologie der Lues des Ohres. In: Handbuch der Hals-Nasen-Ohren-Heilkunde, hrsg. von A. Denker u. O. Kahler, Band 6/Teil 1: 724-744, Springer, Berlin, 1926.

26) Boyd, W.: Pathology, 8th Ed. Lea \& Febiger, Philadelphia, 1970.

27) Ciocco, A.: "Nerve deafness" of known pathology or etiology: Nerve deafness from syphilis. Laryngoscope 47: 572-576, 1937.

28) Goldman, J.N. \& Girard, K.F.: Intraocular treponemes in treated congenital syphilis. Arch. Ophthal. 78; 47-50, 1967.

29) Gstaltner, H.: Zum Krankheitsbild der Lues congenita des Ohres. Mschr. Ohrenheilk. 94: 6770, 1960 ,

30) Haam, E. von: Venereal diseases and spiro. chetal infections. In: Pathology, vol. 1 (pp. 341364), ed. by W.A.D. Anderson, Mosby Co., St. Louis, 1971.

31) Hahn, R.D., et al: Treatment of neural deafness with prednisone. Jour. Chron. Dis. 15: 395$410,1962$.

32) Hendershot, E.L.: Luetic "deafness. Laryngoscope 83: 865-870, 1973 ,

33) Hennebert, C.: Cited from J.B. Nadol, Jr. 1974.

34) Holmes, K.K.: Syphilis. In: Harrison's Principles of Internal Medicine, 7th Ed. (pp. 876-886), ed. by M.M. Wintrobe and others, McGraw-Hill, New York.

35) Karmody, C.S. \& Schuknecht, H.F.: Deafness in congenital syphilis. Arch. Otolaryng. 83: 44-53, 1966.

36) Kerr,A.G., et al: Congenital syphilitic labyrinthitis. Arch. Otolaryng. 91; 474-478, 1970.

37) Kerr, A.G., et al: Congenital syphilitic deafness. Jour. Laryng. Otol. 87; 1-12, 1973.

38) Langenbeck/Lehnhardt: Lehrbuch der praktischen Audiometrie, 4. Auf., Georg Thieme, Stuttgart, 1970.

39) Loch, W.E., \& Tucker, H.A.: Penicillin treatment of nerve deafness due to syphilis. Ann. Otol. (St. Louis) 57 ; 167-180, 1948.

40) Mack, L.W., Ir., et al: Temporal bone trepo- nemes. Arch. Otolaryng. 90: 37-40, 1969.

41) Mayer, O., \& Fraser, J.S.: Pathological changes in the ear in late congenital syphilis. Jour. Laryng. Otol. 61: 683-714, 755-778, 1936.

42) Morton, R.S.: Cortisone therapy in congenital syphilitic nerve deafness. Jour. Laryng. Otol. 71: $850-852,1957$.

43) Murphy, E.A., et al: Nerve deafness associated with congenital syphilis. Report of a case treated with prednisone and penicillin. Jour. Amer. med. Ass. $167 ; 1925-1928,1958$.

44) Nadol, J.B., Jr.: Positive "fistula sign" with an intact tympanic membrane. Arch. Otolaryng. $100 ; 223-278,1974$.

45) Nadol, J.B., Jr.: Hearing loss of acquired syphilis: Diagnosis confirmed by incudectomy. Laryngoscope 85: 1888-1897, 1975.

46) Patterson, M.E.: Congenital luetic hearing impairment-Treatment with prednisone. Arch. Otolaryng. 87: 378-382, 1968.

47) Perlman, H.B., \& Leek, J.H.: Late congenital syphilis of the ear. Laryngoscope 62: 1175-1196, 1952.

48) Perlman, H.B.: Labyrinth capsule lesions with generalized disease of the skeleton. In: Otolaryngology, vol. 2 (pp. 231-240), ed. by M. M. Papa* rella and D.A. Shumrick, Saunders Co., Philadelphia, 1973 .

49) Slatkin, M.H.: Trends in the diagnosis and treatment of syphilis. Med. Clin. N. Amer. 49: $823-842,1965$.

50) Smith, J.L., E Israel, C.W.: The presence of spirochetes in late seronegative syphilis. JAMA 199: 980-984 (March 27), 1967.

51) Smith, J.L., \& Israel, C. W.: Treponemes in aqueous humor in late seronegative syphilis. Trans. Amer. Ophth. Otol. 72; 63-75, 1968.

52) Tamari, M.J., \& Itkin, P.: Penicillin and syphilis of the ear. E.E.N.T. Month. 30: 358-366, 1951.

53) Theissing, G.: Spezifische Erkrankungen des Ohres. In: Hals-Nasen-Ohren-Heilkunde, hrsg. von J. Berendes u. a., Band 3/Teil 2; 1615-1660, Georg 
Thieme, Stuttgart, 1966.

54) Willcox, R.R., \& Goodwin, P.G.: Nerve deafness in early syphilis. Brit. Jour. Vener. Dis. 47:

401-406, 1971.
本稿の要旨は昭和49年10月17日盛凧市に秥ける第19回 日本オージオロジー学会総会に沶いてロ演した， 